\title{
Organochlorine levels in cetaceans from South Africa: A review
}

\author{
V.G. COCKCROFT \\ Centre for Dolphin Studies, Port Elizabeth Museum, PO Box 13147, Humewood, 6013, \\ South Africa. \\ Contact e-mail: pemigc@a-oo.upe.ac.za
}

\begin{abstract}
Publications on levels of organochlorines in cetaceans from South Africa are reviewed. Organochlorine contamination in cetaceans off South Africa is similar to those in Australian waters, but generally low compared to the Northern Hemisphere. An exception is the coastal dolphins inhabiting the South African east coast waters. In these animals levels are similar to Northern Hemisphere coastal cetaceans. Levels are generally higher in coastal dolphins, compared to dolphins living in deeper waters. It is suggested that these differences are directly related to the levels of industrialisation and cultivation of the surrounding area. Too few samples of either baleen whales or toothed whales are available to investigate the differences in organochlorine levels between these two groups. Similarly, even for species with the highest sample sizes - common and bottlenose dolphins - the data are insufficient to investigate trends in contaminant levels.
\end{abstract}

KEYWORDS: POLLUTION-ORGANOCHLORINES; SOUTH ATLANTIC; INDIAN OCEAN: CETACEANS-GENERAL; REVIEW

\section{IVTRODUCTION}

The accumulation of toxic contaminants in marine mammals is of increasing concern (e.g. Reijnders et al., 1999). Marine mammals are long-lived, have large lipid reserves in proportion to their body size and are therefore ideal repositories for high concentrations of the lipophilic chlorinated hydrocarbons. In addition, they appear to lack certain enzymes for the metabolism of some organochlorines; marine mammals appear to accumulate these compounds to a greater degree than other mammals and may therefore be more susceptible to their toxic effects (e.g. Tanabe, 1988; Tanabe et al., 1988).

In common with most of the Southern Hemisphere (Kemper et al., 1994; Marcovecchio et al., 1994), there is little information on the toxic contaminants in the seas surrounding South Africa. Those most frequently studied and reported are the synthetic chiorinated hydrocarbons, the polychlorinated biphenyls (PCBs) and DDT and its metabolites, DDE and DDD. As a result of the intense agricultural usage of land along the eastern coastal zone, particularly in the north (Natal), quantities of DDT entered the marine system prior to 1976, when its use in agriculture was largely discontinued. However, DDT may still be in use, particularly in state managed malaria control procedures in northern Natal (Van Dyk et al., 1982), implying that some may still enter the marine environment. PCBs have never been manufactured in South Africa and their input into the marine environment is, apart from aerial transport, probably limited to leaching from products containing them dumped near to the industrialised areas of Richards Bay and Durban in Natal, East London and Port Elizabeth in the Eastern Cape and Cape Town in the Western Cape.

There are some published data for organochlorine residues in coastal birds (De Kock and Randall, 1984) and seals (Cockcroft et al., 1991), although most of this emanates from samples collected and processed in the 1970s and 1980s. More recently, samples have been 
routinely collected from cetaceans stranded and incidentally captured, however, the high analytical costs have limited the analyses. This paper reviews the data available in published papers and technical reports.

\section{STUDY AREA}

South Africa has a coastline of about $3,000 \mathrm{~km}$ and is bounded by two major current systems. To the west, the cold and intermittent Benguela Current runs northwards, while to the east, the warm, strongly flowing Agulhas Current runs in a southerly direction (Fig. 1). Other than in the south, around Cape Town, the west coast is mostly arid, human population density is low and industrialisation and agriculture limited. In contrast, the coastal belt of the east coast is generally moist, fairly heavily cultivated and has several large cities $(>500,000$ inhabitants), all of which have an active industrial base.

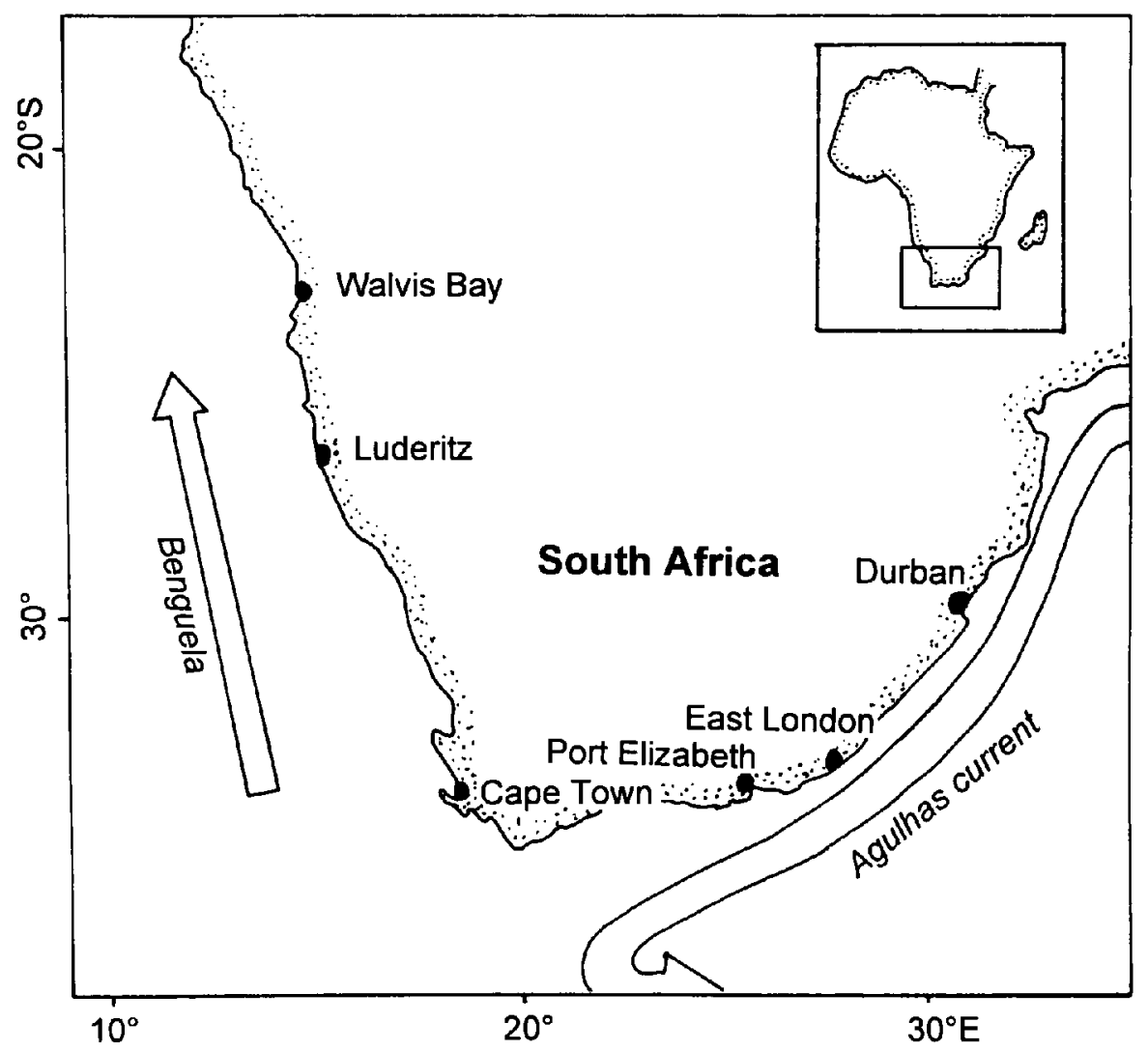

Fig. 1. South Africa is bounded by two current systems, the cold Benguela to the west and the warm, strongly flowing Agulhas to the east. The primary centres of industrialisation, agriculture and habitation are either on, or drain to, the east coast, east of longitude $20^{\circ} \mathrm{E}$.

For the purpose of this review, the west coast of South Africa is taken to be that part of the coastline west and north of the southern tip of Africa (about $20^{\circ} \mathrm{E}$ ). The east coast is taken to be that part of the coast east of this point. 


\section{METHODOLOGY}

For animals sampled from the west coast, both stranded and taken by scientific permit, blubber was taken dorsally, anterior to the dorsal fin, wrapped in aluminium foil and stored at $-20^{\circ} \mathrm{C}$ until analysis. For the east coast, using both strandings and incidental captures, blubber samples were taken just anterior to either pectoral flipper, wrapped in aluminium foil and frozen at $-20^{\circ} \mathrm{C}$ for analysis. Analyses for all west coast samples and samples from incidentally caught dolphins on the east coast followed the methodology described by Cockcroft et al. (1989) and De Kock (1990) .

For east coast animals, sample extraction, clean up and analyses followed the methodology of Watling (1981) and Henry and Best (1983). Briefly, lipid from thawed samples $(5-10 \mathrm{~g})$ was extracted by ultrasonic maceration with hexane. This was cleaned up using a silica gel and sodium sulphate column. Two fractions, the first containing the PCBs and DDTs, the second Dieldrin and most of the Lindane, were subsequently obtained. Samples were analysed using a PYE gas liquid chromatograph (GLC - tuned to approximately $250 \mathrm{~g} \times 10^{-12} / \mu \mathrm{l}$ sensitivity) with an electron capture detector. Compounds were quantified by frequent calibration of the GLC with external standards (Environmental Protection Agency, USA). Occasionally, further confirmation was done by ultraviolet photalysis.

\section{RESULTS}

\section{West coast}

De Kock et al. (1994) provide total PCB, HCB and DDT concentrations for 72 cetaceans of 15 species stranded or taken by scientific permit off the west coast between 1977 and 1987 (Table 1). Overall, levels of DDT and PCB were low and Dieldrin was present in only a small proportion of the samples.

\section{East coast}

The concentrations of tDDT in 36 rorquals ( 6 fin, 1 sei and 29 minke) landed at Durban during the 1974 whaling season were all exceptionally low $(<1 \mu \mathrm{g} / \mathrm{kg}$ wet weight), while PCB levels were too low to be detectable (Henry and Best, 1983). Similarly, concentrations of tDDT in 12 sperm whales landed in the same year, were also extremely low $(<1.3 \mu \mathrm{g} / \mathrm{kg}$ wet weight), with no detectable level of PCBs.

A study of organochlorines (Cockcroft et al., 1991) in the blubber of 41 odontocete cetaceans stranded off the east coast of South Africa between 1976 and 1981, showed highly variable results (Table 2). Generally, cetaceans from the Eastern Cape showed lower tDDT, PCB, Dieldrin and Lindane levels than did those from Natal. Additionally, those inhabiting coastal waters displayed higher levels of all contaminants than did animals from pelagic waters.

The results of pollutant studies of common and bottlenose dolphins incidentally captured in shark nets off Natal (Cockcroft, 1990) were similar to those of other studies of contaminants in cetaceans (Cockcroft et al., 1989; 1990). For both species, contaminant levels were considerably higher in the blubber than in the liver. Contaminant concentrations in males increased with age (based on growth layer group - GLG - counts), whereas concentrations in females showed a marked and rapid decline at sexual maturity (Tables 3 and 4). Most interesting was the finding that, in both species, this decline occurred subsequent to the females' first or second ovulation, implying that primiparous females rid themselves of the major portion of their contaminant burden to either the first and/or the second born calf, probably via lactation (Cockcroft et al., 1989; 1990). 
Table 1

Organochlorine residue levels $(\mu / \mathrm{g}$ wet weight $)$ in the blubber of cetaceans from the west coast of South Africa (1977-1987) (from de Kock et al.. 1994).

\begin{tabular}{|c|c|c|c|c|c|c|c|}
\hline Species & $\mathrm{n}$ & Year & Sex & Length (m) & tDDT & PCB & $\mathrm{HCB}$ \\
\hline Southern right whale & 2 & 1984 & M & 9.25 & 0.01 & 0.01 & 0.02 \\
\hline (Eubalaena australis) & & 1986 & M & 4.85 & 0.01 & 0.01 & 0.01 \\
\hline $\begin{array}{l}\text { Pygmy right whale } \\
\text { (Caperea marginata) }\end{array}$ & 1 & 1987 & $\mathrm{~F}$ & 6.5 & 0.05 & 0.12 & 0.01 \\
\hline $\begin{array}{l}\text { Minke whale } \\
\text { (Balaenoptera acutorostrata) }\end{array}$ & 1 & 1984 & $\mathbf{F}$ & 3.3 & 0.08 & 0.01 & 0.1 \\
\hline $\begin{array}{l}\text { Sperm whale } \\
\text { (Physeter macrocephalus) }\end{array}$ & 1 & 1986 & $\mathrm{~F}$ & 16 & 0.39 & 0.13 & 0.01 \\
\hline Pygmy sperm whale & $s$ & 1978 & $\mathrm{~F}$ & 2.93 & 0.51 & 0.26 & 0.06 \\
\hline \multirow[t]{4}{*}{ (Kogia breviceps) } & & 1984 & $\mathbf{F}$ & 3.01 & 0.3 & 0.12 & 0.05 \\
\hline & & 1986 & $\mathbf{F}$ & 3.21 & 1.02 & 1.1 & 0.06 \\
\hline & & 1986 & M & 2.18 & 1.11 & 0.29 & 0.08 \\
\hline & & 1987 & $\mathbf{M}$ & 2.33 & 0.3 & 0.26 & 0.03 \\
\hline Dwarf sperm whale & 4 & 1976 & $\mathbf{M}$ & 1.67 & 1.43 & 0.18 & 0.04 \\
\hline \multirow[t]{3}{*}{ (Kogia simus) } & & 1984 & $\mathbf{M}$ & 2.11 & 0.37 & 0.15 & 0.03 \\
\hline & & 1984 & $\mathbf{M}$ & 2.3 & 0.54 & 0.29 & 0.03 \\
\hline & & 1984 & $\mathbf{M}$ & 1.78 & 0.65 & 0.38 & 0.03 \\
\hline Blainville's beaked whale & 6 & 1984 & $\mathrm{~F}$ & 3.46 & 1.47 & 0.88 & 0.15 \\
\hline \multirow[t]{5}{*}{ (Mesoplodon densirostris) } & & 1984 & $\mathrm{~F}$ & 4.54 & 0.29 & 0.3 & 0.02 \\
\hline & & 1984 & M & 2.25 & 1.86 & 0.29 & 0.16 \\
\hline & & 1984 & $\mathrm{~F}$ & 4.54 & 0.38 & 0.51 & 0.03 \\
\hline & & 1984 & $\mathrm{~F}$ & 4.25 & 0.36 & 0.27 & 0.03 \\
\hline & & 1986 & $\mathbf{M}$ & 3.76 & 0.39 & 0.26 & 0.02 \\
\hline True's beaked whale & 2 & 1986 & F & 3.19 & 0.91 & 1.22 & 0.09 \\
\hline (Mesoplodon mirus) & & 1986 & $\mathbf{F}$ & 4.17 & 1.37 & 0.75 & 0.11 \\
\hline Layard's beaked whale & 2 & 1978 & $\mathrm{M}$ & 2.9 & 0.54 & 0.15 & 0.13 \\
\hline (Mesoplodon layardi) & & 1985 & $\mathrm{M}$ & 5.2 & 1.22 & 1.93 & 0.27 \\
\hline Risso's dolphin & 2 & 1984 & $\mathrm{M}$ & 3.14 & 7.51 & 2.72 & 0.02 \\
\hline (Grampus griseus) & & 1986 & $\mathrm{~F}$ & 1.29 & 1.29 & 0.39 & 0.03 \\
\hline Striped dolphin & 2 & 1984 & $\mathrm{~F}$ & 2.3 & 1.02 & 1.28 & 0.02 \\
\hline (Stenella coeruleoalba) & & 1986 & $\mathrm{M}$ & 2.01 & 0.74 & 1.11 & 0.03 \\
\hline Bottlenose dolphin & 6 & 1976 & M & 2.69 & 4.14 & 0.34 & 0.03 \\
\hline \multirow[t]{5}{*}{ (Tursiops truncatus) } & & 1980 & $\mathrm{M}$ & 2.86 & 0.17 & 0.16 & 0.01 \\
\hline & & 1984 & M & 1.35 & 2.52 & 1.93 & 0.01 \\
\hline & & 1985 & M & 1.72 & 3.6 & 2.33 & 0.03 \\
\hline & & 1985 & M & 2.61 & 12.29 & 8.29 & 0.03 \\
\hline & & 1987 & $\mathrm{~F}$ & 2.88 & 1.75 & 1.62 & 0.01 \\
\hline Common dolphin & 17 & 1984 & M & 2.08 & 9.63 & 6.94 & 0.4 \\
\hline \multirow[t]{16}{*}{ (Delphinus delphis) } & & 1984 & M & 2.22 & 0.48 & 0.43 & 0.02 \\
\hline & & 1984 & M & 2.3 & 5.73 & 3.39 & 0.02 \\
\hline & & 1984 & M & 1.97 & 0.07 & 0.07 & 0.02 \\
\hline & & 1984 & $M$ & 1.49 & 13.69 & 12.27 & 0.16 \\
\hline & & 1984 & M & 1.55 & 25.25 & 15.51 & 0.18 \\
\hline & & 1984 & $F$ & 2.15 & 3.02 & 2.61 & 0.04 \\
\hline & & 1986 & M & 2.07 & 9.83 & 2.88 & 0.02 \\
\hline & & 1986 & $\mathrm{M}$ & 1.97 & 9.58 & 5.75 & 0.05 \\
\hline & & 1986 & M & 2.07 & 5.49 & 5.41 & 0.01 \\
\hline & & 1986 & $\mathrm{M}$ & 2.43 & 7.73 & 4.18 & 0.01 \\
\hline & & 1986 & $\mathrm{~F}$ & 2.11 & 2.96 & 2.96 & 0.01 \\
\hline & & 1986 & $\mathrm{~F}$ & 1.95 & 0.96 & 1.12 & 0.05 \\
\hline & & 1986 & $\mathrm{~F}$ & 2.2 & 2.68 & 5.07 & 0.05 \\
\hline & & 1987 & $\mathrm{~F}$ & 2.17 & 0.57 & 0.59 & 0.02 \\
\hline & & 1987 & $\mathrm{~F}$ & 1.62 & 2.88 & 5.03 & 0.08 \\
\hline & & 1987 & $\mathrm{~F}$ & 2.29 & 0.71 & 2.41 & 0.05 \\
\hline
\end{tabular}


Table I continued

\begin{tabular}{|c|c|c|c|c|c|c|c|}
\hline Species & $\mathrm{n}$ & Year & Sex & Length $(\mathrm{m})$ & tDDT & PCB & $\mathrm{HCB}$ \\
\hline Heaviside's dolphin & 9 & 1977 & $\mathrm{~F}$ & 1.68 & 1.17 & 0.11 & 0.04 \\
\hline \multirow[t]{8}{*}{ (Cephalorhynchus heavisidii) } & & 1982 & $\mathrm{~F}$ & 1.58 & 4.21 & 0.65 & 0.06 \\
\hline & & 1984 & $\mathbf{M}$ & 1.47 & 4.77 & 1.76 & 0.06 \\
\hline & & 1984 & M & 1.56 & 2.71 & 0.75 & 0.01 \\
\hline & & 1984 & M & 1.56 & 1.96 & 0.65 & 0.08 \\
\hline & & 1985 & NA & NA & 0.26 & 1.09 & 0.02 \\
\hline & & 1985 & $\mathrm{~F}$ & 1.18 & 0.25 & 0.07 & 0.01 \\
\hline & & 1985 & M & 1.51 & 3.61 & 1.13 & 0.04 \\
\hline & & 1987 & $M$ & 1.53 & 0.78 & 0.27 & 0.03 \\
\hline Dusky dolphin & 12 & 1977 & $\mathbf{F}$ & 0.85 & 2.74 & 0.64 & 0.01 \\
\hline \multirow[t]{11}{*}{ (Lagenorhynchus obscurus) } & & 1977 & $\mathbf{M}$ & 1.69 & 16.15 & 2.29 & 0.02 \\
\hline & & 1984 & M & 1.66 & 13.74 & 5.59 & 0.14 \\
\hline & & 1984 & $\mathrm{~F}$ & 1.69 & 1.49 & 2.37 & 0.06 \\
\hline & & 1986 & $\mathrm{~F}$ & 1.61 & 1.69 & 1.17 & 0.01 \\
\hline & & 1986 & $\mathrm{~F}$ & 1.71 & 1.31 & 0.56 & 0.03 \\
\hline & & 1986 & $\mathrm{~F}$ & 1.87 & 1.04 & 0.76 & 0.02 \\
\hline & & 1986 & $\mathrm{M}$ & 1.84 & 8.17 & 4.24 & 0.06 \\
\hline & & 1986 & M & 0.89 & 0.49 & 0.38 & 0.02 \\
\hline & & 1987 & $F$ & 1.78 & 5.82 & 1.71 & 0.04 \\
\hline & & 1987 & $\mathrm{M}$ & 1.76 & 2.21 & 1.58 & 0.05 \\
\hline & & 1987 & $\mathrm{M}$ & 0.92 & 1.21 & 1.89 & 0.07 \\
\hline
\end{tabular}

\section{CONCLUSIONS}

Although conclusions from available data are confounded by the variety of cetacean species sampled and differences in the sex and level of maturity of individuals, it appears that organochlorine contamination in cetaceans off South Africa is similar to that in Australian waters (Kemper et al., 1994), but generally low in comparison with the Northern Hemisphere. Nevertheless, coastal dolphins, particularly those inhabiting South African east coastal waters, appear to be an exception to this pattern and show levels similar to Northern hemisphere coastal cetaceans (Wagemann and Muir, 1984).

On both the west and east coasts of South Africa, coastal dolphins (common, bottlenose, Heaviside's and dusky dolphins) generally show higher contaminant levels than do those cetaceans inhabiting deeper waters. As an example, Indo-Pacific hump-backed dolphins (Sousa chinensis) from Natal are never seen in waters deeper than $20 \mathrm{~m}$ and show the highest organochlorine concentrations of any marine mammal in South African waters (Gardner et al., 1983; Cockcroft, unpublished data). Regardless of the influences of dolphin prey preferences and movement patterns, differential hinterland development of industry and agriculture, or the effect of unknown factors, these data imply that inshore waters are generally more contaminated than deeper waters, even within the coastal belt out to $200 \mathrm{~m}$ depth.

Despite the occurrence of one mature male bottlenose dolphin from the west coast with PCB levels similar to those for east coast males, there is strong evidence that contaminant levels in cetaceans are related to the level of agricultural and industrial development of the surrounding area. Coincident with agricultural and industrial development, bottlenose dolphins captured in northern Natal, from Durban northwards, display significantly higher levels of PCBs, DDT and Dieldrin than do those from the south (Cockcroft et al., 1989). This clearly suggests that coastal contaminant levels are directly related to the levels of industrialisation and cultivation of adjacent land areas. 
Table 2

Chlorinated hydrocarbon residue concentrations ( $\mu \mathrm{g} / \mathrm{g}$ wet weight) in the blubber of cetaceans stranded on the east coast of South Africa (tDDT=DDT+DDE+TDE, JD = just detectable $<0.01, \mathrm{ND}=$ not detectable).

\begin{tabular}{|c|c|c|c|c|c|c|c|c|c|c|c|}
\hline Species & $\begin{array}{l}\text { Length } \\
(\mathrm{cm})\end{array}$ & $\begin{array}{c}\text { Weight } \\
(\mathrm{kg})\end{array}$ & Sex & PCB & DDE & TDE & DDT & Diel & Lind & tDDT & $\begin{array}{r}\text { DDE/ } \\
\text { TDDT }\end{array}$ \\
\hline \multicolumn{12}{|l|}{ Eastern Cape } \\
\hline Grampus griseus & 2120 & 84.8 & $\mathbf{F}$ & ND & 0.86 & 0.54 & 1.79 & ND & & 1.40 & 0.61 \\
\hline$G$ griseus & 2540 & & $\mathbf{F}$ & ND & 0.61 & 0.37 & 1.07 & ND & & 0.98 & 0.62 \\
\hline G. griseus & 2980 & 304 & M & ND & 4.37 & 0.07 & 0.40 & ND & ND & 4.44 & 0.98 \\
\hline G. griseus & 2640 & 185 & M & ND & 1.93 & ND & ND & $\mathrm{ND}$ & ND & 1.93 & 1.00 \\
\hline Tursiops truncatus & 1075 & 14.5 & $\mathbf{F}$ & ND & 0.42 & 0.02 & 0.11 & 0.03 & ND & 0.44 & 0.96 \\
\hline T. truncatus & 1160 & 46.5 & $\mathrm{~F}$ & 4.23 & 5.37 & ND & 1.27 & 0.06 & & 9.60 & 0.56 \\
\hline T. truncatus & 950 & 9.5 & $\mathrm{~F}$ & ND & 0.32 & 0.59 & ND & 0.04 & & 0.91 & 0.35 \\
\hline T. truncatus & 2250 & & M & 10.02 & 2.40 & ND & 0.97 & 2.95 & & 12.42 & 0.19 \\
\hline T. truncatus & 1050 & 17.7 & M & 2.57 & 23.68 & ND & 0.50 & 0.03 & & 26.25 & 0.90 \\
\hline T. truncatus & 1040 & 30.3 & M & ND & 6.86 & ND & ND & 0.09 & & 6.86 & 1.00 \\
\hline T. truncatus & & & $\mathbf{M}$ & ND & 0.87 & 1.16 & 1.00 & 0.09 & & 2.03 & 0.43 \\
\hline Stenella coeruleoalba & & & & ND & 1.21 & ND & ND & ND & & 1.21 & 1.00 \\
\hline S. coeruleoalba & & & & ND & 2.49 & 0.82 & 1.74 & 0.04 & & 3.31 & 0.75 \\
\hline S. coeruleoalba & 2280 & 128 & $\mathrm{~F}$ & ND & 6.54 & ND & ND & ND & & 6.54 & 1.00 \\
\hline S. coeruleoalba & 2150 & 78.5 & M & ND & 1.82 & ND & ND & 0.16 & & 1.82 & 1.00 \\
\hline Orcinus orca & 6050 & 3067 & M & ND & 7.84 & 3.70 & 8.45 & 0.04 & & 11.54 & 0.68 \\
\hline Mesoplodon densirostris & 2300 & 157 & $\mathrm{~F}$ & ND & ND & ND & ND & ND & & ND & \\
\hline M. densirostris & 3510 & 468 & F & 1.71 & 2.79 & ND & 0.43 & JD & & 4.50 & 0.62 \\
\hline M. densirostris & 4500 & & $\mathrm{~F}$ & ND & ND & ND & ND & ND & & ND & \\
\hline M. densirostris & 4650 & & $\mathrm{M}$ & 0.45 & 1.71 & ND & 0.32 & 0.02 & & 2.16 & 0.79 \\
\hline Delphinus delphis & 2280 & 107 & $\mathrm{M}$ & ND & 5.61 & ND & 1.04 & 0.43 & ND & 5.61 & 1.00 \\
\hline D. delphis & 2210 & 112 & $\mathbf{M}$ & ND & ND & 0.17 & 0.34 & 0.02 & & 0.17 & JD \\
\hline D. delphis & 1385 & 27.5 & $\mathbf{M}$ & ND & 0.48 & 0.02 & JD & 0.02 & ND & 0.49 & 0.99 \\
\hline D. delphis & 1210 & 37.5 & M & 4.33 & 10.77 & ND & 1.88 & 0.08 & & 15.10 & 0.71 \\
\hline D. delphis & 2280 & 112 & M & 6.82 & 12.90 & JD & 0.51 & ND & JD & 19.72 & 0.65 \\
\hline Kogia simus & 2650 & & & ND & 0.61 & ND & ND & ND & ND & 0.61 & 1.00 \\
\hline$K$. simus & & & & ND & 0.07 & ND & $\mathrm{ND}$ & ND & ND & 0.07 & 1.00 \\
\hline$K$. simus & 2200 & 156 & $\mathrm{~F}$ & ND & 0.32 & 0.14 & 0.44 & ND & & 0.45 & 0.70 \\
\hline K. simus & 1470 & 61.5 & $\mathrm{~F}$ & ND & 0.04 & ND & 0.07 & ND & & 0.04 & 1.00 \\
\hline K. simus & & & M & 1.77 & 3.09 & ND & 0.25 & 0.02 & ND & 4.86 & 0.64 \\
\hline K. breviceps & 2560 & 177 & $\mathbf{M}$ & ND & 1.01 & ND & ND & 0.04 & & 1.01 & 1.00 \\
\hline Physeter mac & 3720 & & $F$ & ND & 0.09 & 0.04 & 0.08 & ND & & 0.13 & 0.69 \\
\hline P. macrocephalus & 4080 & & M & ND & 0.20 & ND & ND & ND & ND & 0.20 & 1.00 \\
\hline \multicolumn{12}{|l|}{ Natal } \\
\hline G. griseus & 2033 & 81.5 & M & ND & ND & ND & ND & 0.11 & ND & ND & \\
\hline Stenella attenuata & 1880 & 51.4 & $\mathrm{~F}$ & 30.60 & 32.00 & 1.27 & 0.52 & 0.04 & ND & 63.87 & 0.50 \\
\hline S. attenuata & 1740 & 45.5 & $\mathrm{M}$ & 48.30 & 16.90 & ND & 3.45 & 0.07 & ND & 65.20 & 0.26 \\
\hline S. attenuata & 1820 & 55.5 & M & 8.73 & 8.83 & 1.60 & 3.37 & ND & & 19.16 & 0.46 \\
\hline S. attenuata & 2200 & 84.1 & $\mathrm{M}$ & 4.78 & 2.65 & 0.17 & ND & ND & & 7.60 & 0.35 \\
\hline T. truncatus & 1020 & & M & 22.90 & 13.60 & 0.71 & 4.95 & 0.19 & 0.03 & 37.21 & 0.37 \\
\hline S. coeruleoalha & 1860 & 76 & $\mathrm{M}$ & ND & 2.30 & 1.17 & 2.85 & ND & & 3.47 & 0.66 \\
\hline Hyperoodon planifrons & 2910 & 228 & M & ND & 1.20 & 0.40 & 2.99 & 0.07 & & 1.60 & 0.75 \\
\hline
\end{tabular}

Despite the lack of direct cause and effect information for cetaceans, there is sufficient indirect information for the high levels of contaminants in coastal dolphins to warrant concern (see Reijnders et al., 1999). Not only are levels in mature males possibly high enough to impair reproductive capacity (Cockcroft et al., 1989), but the build up and 
reproductive transfer to offspring of contaminants in primiparous females could have important implications. With respect to build-up, high concentrations of organochlorines in pregnant females can potentially cause developmental problems in offspring (e.g. Colborn and Clement, 1992). Interpolation from a study of the milk consumption of a captive bottlenose dolphin calf (Cockcroft and Ross, 1990) suggests that primiparous females transfer, via lactation, the major portion of their contaminant load within six to eight weeks post partım. The implications of the rapid mobilisation and metabolism of such quantities of contaminants on the primiparous female are unknown. Similarly, the ingestion of the majority of the female's organochlorine load over a short period exposes first born calves to massive doses of contaminants and raises concern for the calf's survival. Both aspects warrant further investigation and should be considered in the conservation and management of coastal dolphins.

Table 3

Mean concentrations $(\mu \mathrm{g} / \mathrm{g}$ wet weight) of PCBs and tDDT in different common dolphin sex and age classes (from Cockcroft et al., 1990).

\begin{tabular}{lccc}
\hline & Sample size & PCB & tDDT \\
\hline Immatures (<10 GLGs) & 42 & 4.8 & 4.0 \\
Resting females & 11 & 3.9 & 3.8 \\
Lactating females & 18 & 1.9 & 0.9 \\
Pregnant females & 9 & 1.7 & 1.5 \\
Mature males & 17 & 7.9 & 6.4 \\
\hline
\end{tabular}

Baleen whales in general show significantly lower levels of contaminants than odontocetes. Although this may be related to their diet, their predominantly offshore occurrence and the fact that most make seasonal migrations to high latitudes are also probable factors (see review by O'Shea and Brownell, 1994). Too few samples of any one species from the region discussed in this paper are available for an unequivocal interpretation.

Table 4

Mean concentrations ( $\mu \mathrm{g} / \mathrm{g}$ wet weight) of PCBs and tDDT in different bottlenose dolphin sex and age classes (from Cockcroft et al., 1989). n = sample size.

\begin{tabular}{lcccccc}
\hline & $\mathbf{n}$ & PCB & $\mathbf{n}$ & TDDT & $\mathbf{n}$ & Dieldrin \\
\hline Calves & 38 & 8.57 & 37 & 10.3 cent2 & 33 & 0.51 \\
Adolescents & 18 & 13.5 & 18 & 11.25 & 15 & 0.38 \\
Lactating females & 14 & 2.5 & 13 & 1.25 & 8 & 0.04 \\
Mature males & 17 & 8.43 & 16 & 38.3 & 15 & 0.21 \\
\hline
\end{tabular}

In summary, there are insufficient data from the South African region to construct a clear picture of contaminant dynamics in cetaceans. Even for the species with the highest sample sizes (common and bottlenose dolphins), the lack of data since 1987 precludes any interpretation of recent or long-term trends. Consequently, there is an urgent need for further studies, particularly of collected and archived samples, where only the lack of funding hinders analysis. Future studies should include the use of biopsy samples (e.g. Aguilar and Borrell, 1994) and innovative assessments of contaminant effects. For example, sampling of 
both dead and free-ranging cetaceans should be combined with pathological examinations in order to assess the actual impact of pollutants on the health of cetacean individuals and populations.

\section{REFERENCES}

Aguilar, A. and Borrell, A. 1994. Assessment of organochlorine pollutants in cetaceans by means of skin and hypodermic biopsies. pp. 245-67. In. M.C. Fossi and C. Leonzio (eds.) Non-Destructive Biomarkers in Vertebrates. Lewis Publishers, Boca Raton, Florida. 457pp.

Cockeroft, V.G. 1990. Dolphin catches in the Natal shark nets, 1980-1988. S. Afr. J. Wildl. Res. 20(2):44-51.

Cockcroft, V.G. and Ross, G.J.B. 1990. Observations on the early development of a captive bottlenose dolphin calf. pp. 461-78. In: S. Leatherwood and R. Reeves (eds.) The Bottlenose Dolphin. Academic Press, New York. 653pp.

Cockcroft, V.G., De Kock, A.C., Lord, D.A. and Ross, G.J.B. 1989. Organochlorines in bottlenose dolphins, Tursiops truncatus, from the east coast of South Africa. S. Afr. J. mar. Sci. 8:207-17.

Cockcroft, V.G., De Kock, A.C., Ross, G.J.B. and Lord, D.A. 1990. Organochlorines in common dolphins caught in shark nets during the Natal 'sardine run', S. Afr. J. Zool. 25(2): 144-8.

Cockcroft, V.G., Ross, G.J.B., Connell, A.D., Gardener, B.D. and Butler, A.C. 1991. Occurence of organochlorines in stranded cetaceans and seals from the east coast of Southern Africa. UNEP Mar. Marmmal Tech. Rep. 3:271-82.

Colborn, T. and Clement, C. 1992. Consensus statement: statement from the work session on chemically induced alterations in sexual development: the wildlife/human connection. p.8. In: T. Colborn and C. Clement (eds.) Chemically Induced Alterations in Sexual and Functional Development: the Wildife Connection. Princeton Scientific Publishing, Princeton, New Jersey.

De Kock, A.C. 1990. Chlorinated hydrocarbons as chemical tracers of marine contamination. Ph.D. Thesis, University of Port Elizabeth, South Africa.

De Kock, A.C. and Randall, R.M. 1984. Organochlorine insecticide and polychlorinated biphenyl residues in eggs of coastal birds from the Eastern Cape, South Africa. Emiron. Pollut. 35:193-201.

De Kock, A.C., Best, P.B., Cockcroft, V. and Nosma, C. 1994. Persistent organochlorine residues in small cetaceans from the east and west coasts of Southern Africa. Sci. Total Environ. 154(2-3):153-62.

Gardner, B.D., Comell, A.D., Eagle, G.A., Molden, A.G.S., Oliff, W.D., Orren, M.J. and Watling, R.J. 1983. South African marine pollution survey report 1976-1979. S. Afr. Natl Sci. Program. Rep. 73:87-91.

Henry, J. and Best, P.B. 1983. Organochlorine residues in whales landed at Durban, South Africa. Mar. Poll. Bull. 14(6):223-7.

Kemper, C., Gibbs, P., Obendorf, D., Marvanek, S. and Lenghaus, C. 1994. A review of heavy metal and organochlorine levels in marine mammals in Australia. Sci. Total Emiron. 154(2-3):129-39.

Marcovecchio, J.E., Gerpe, M.S., Bastida, R.O., Rodríguez, D.H. and Morón, S.G, 1994. Environmental contamination and marine mammals in coastal waters from Argentina: an overview. Sci. Total Emiron. 154:141-51.

O'Shea, T.J. and Brownell, R.L. 1994. Organochlorine and metal contaminants in baleen whales - a review and evaluation of conservation implications. Sci. Total Emiron. 154(2-3):179-200.

Reijnders, P.J.H., Donovan, G.P., Aguilar, A. and Bjørge, A. 1999. Report of the Workshop on Chemical Pollution and Cetaceans. J. Cetacean Res. Manage. (special issue 1):1-42.

Tanabe, S. 1988. PCB problems in the future: foresight from current knowledge. Emviron. Pollut 50:5-28.

Tanabe, S., Watanabe, S., Kan, H. and Tatsukawa, R. 1988. Capacity and mode of PCB metabolism in small cetaceans. Mar. Mammal Sci. 4(2):103-24.

Van Dyk, L.P., Wiese, I.H. and Mullen, J.E.C. 1982. Management and determination of pesticide residues in South Africa. Residue Rev. 82:37-124.

Wagemann, R. and Muir, D.G.C. 1984. Concentrations of heavy metals and organochlorines in marine mammals of northern waters: overview and evaluation. Can. Trch. Rep. Fish. Aquat. Sci. 1279:1-97.

Watling, R.J. 1981. A manual of methods for use in the South Africatn marine pollution monitoring programme. S. Afr. Natl Sici. Program. Rep. 44:1-79. 